UDC 636.2.09:616.379-008.64

Review paper

doi: 10.5937/AASer1846233C

Acta Agriculturae Serbica, Vol. XXIII, 46 (2018); 233-245

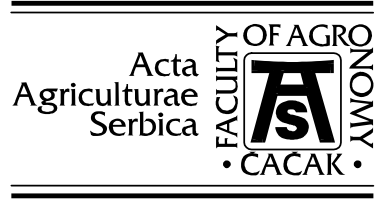

\title{
Insulin resistance in cows during the periparturient period (Review)
}

\author{
Marko R. Cincović ${ }^{1}$, Radojica Đoković ${ }^{2}$, Branislava Belić ${ }^{1}$, Ivana \\ Lakić $^{1}$, Nenad Stojanac ${ }^{1}$, Ognjen Stevančević ${ }^{1}$, Nenad Staničkov ${ }^{1}$ \\ ${ }^{1}$ University of Novi Sad, Faculty of Agriculture, Department of veterinary \\ medicine; \\ Trg Dositeja Obradovića 8, 21000 Novi Sad, Serbia \\ ${ }^{2}$ University of Kragujevac, Faculty of Agronomy Čačak, Cara Dušana 34, Čačak, \\ Serbia \\ Corresponding author: mcincovic@gmail.com
}

\begin{abstract}
Insulin resistance is a state in which the biological effect of insulin is reduced when its concentration decreases or when a compensatory mechanism increases its concentration. Insulin resistance is characterized by reduced insulin response to glucose, i.e. decreased pancreatic beta cell function (insulin hyporesponsiveness) and/or reduced sensitivity of glucose to insulin (reduced intake of glucose by peripheral tissues under the influence of insulin - eng. insulin sensitivity). Methods for estimating insulin resistance include direct methods (hyperinsulinaemic-euglycaemic clamp, golden standard), indirect methods (intravenous glucose tolerance test) and surrogate methods (indices calculated from basal concentrations of insulin, glucose, NEFA and BHB-HOMA, QUICKI, RQUICKI and RQUICKI- BHB). Surrogate indices show correlations with direct and indirect test results but they are inconsistent. Inconsistency occurs because the dependence of glucose concentrations on the degree of hepatic gluconeogenesis should be kept in mind when evaluating insulin resistance in ruminants. Therefore, the hyperinsulinaemic-euglicaemic clamp method is particularly suitable as it excludes gluconeogenesis in hepatocytes from analysis. Our results have shown a correlation between HOMA, QUICKI and RQUICKI indices and metabolic profile parameters. The correlation between dynamic and basal responses of NEFA, BHB, insulin, glucose and inorganic phosphorus is significantly dependent on RQUICKI- BHB index values in
\end{abstract}

Received 27 November 2018 Accepted 5 December 2018 
ketotic cows. RQUICKI index of insulin resistance is substantially dependent on NEFA values in early lactation as well as on insulin and glucose values in the dry period. Further investigations should focus on the practical evaluation of the use of insulin resistance indices.

Key words: insulin resistance indices, cows, metabolic stress, early lactation.

\section{Role and regulation of insulin secretion}

Insulin is the main hormone in all adaptive processes during metabolic stress in peripartal cows. Research on insulin resistance has become a crucial point in understanding peripartal metabolism.

Insulin has a major influence on nutrient partitioning to particular tissues and mammary glands. Insulin is an antilipolytic and antiketogenic hormone that has a major role in appetite regulation. Insulin is a polypeptide constructed from amino acids connected by disulfide bonds and it is secreted from Langerhans cells of the pancreas. The Nobel prize for the discovery of insulin was awarded to Canadian physiologist Frederic Grant Banting (Pavlović and Pavlović, 2007).

Insulin actions at the cellular level are mediated by mRNA transcription and translocation, which affect the metabolism of glucose, proteins and fats (Wilcox, 2005). Glucose enters in the cell through different glucose transport proteins (GLUT) which can act without the presence of insulin (GLUT1 in the brain and erythrocytes; GLUT2 in tubular cells, epithelial cells of the small intestine and the liver, GLUT3 in neurons and placenta) or with insulin action (GLUT4 fat tissue, muscle tissue). As regards carbohydrate metabolism, insulin increases the production of glycogen and reduces glycogenolysis by dephosphorylation of glycogen synthase i.e. glycogen- phosphorylase. Insulin increases the conversion of pyruvate to acetyl CoA by activation of the intramitochondrial pyruvate dehydrogenase complex. Acetyl CoA can further be oxidized in the Krebs cycle or fatty acids can be synthesized. Another aspect of insulin action is that insulin stimulates the synthesis of fatty acids in adipose tissue. Fatty acid synthesis increases with increasing phosphorilation of acetyl-CoA carboxylase. Suppression of fatty acid oxidation is allowed by carnitine-acyltransferase inhibition. Insulin induces protein synthesis in many tissues. It is in charge of mRNA transcription and mRNA translocation in ribosomes. Examples of increased mRNA transcription include mRNA for glucokinase, phosphokinase, synthesis of fatty acids and albumins in the liver and pyruvate carboxylase in adipose tissue. Insulin reduces mRNA for hepatic enzymes, such as carbamoyl phosphate synthetase, which is the main enzyme in the urea cycle. Insulin is in charge of the synthesis of many growth factors, such as IGF-I.

There are many factors that affect insulin secretion in cows. Stimulators are: glucoses, galactose, xylitol, glyceraldehyde, many amino acids, fatty acids, sodium, vagus stimulation, calcium, gastrointestinal hormones (glucagon, 
cholecystokinin, pancreatic peptides, secretin) and some medications. Factors that cause insulin suppression are: greater body mass (related to increased lipolysis and higher concentrations of lower fatty acids in the blood), gastrointestinal hormones (galanin and somatostatin), sympathetic activity (hormones produced by the adrenal glands), inflammation mediators and full hormones (Pyerzinowski and Zabielski, 1999; Wilcox, 2005; Hayirli, 2006). Many of these factors together affect insulin secretion in the peripartal period. Beta pancreatic cells have IGF-I and insulin receptors, which can allow additional insulin secretion after an increase in blood glucose levels. Insulin allows beta cells to detect glucose levels and regulates growth and regeneration of beta cells (Kulkarni, 2004).

Considering reduced feed intake and negative energy balance as main adaptation processes in early lactation related to insulin resistance, the degree to which insulin reduces body condition score and feed intake should be analyzed (Anil et al., 1980; Deetz and Wangsness, 1980; Foster et al., 1991). In peripheral insulin administration, glucose concentrations were reduced (because glucose enters cells), which is a main factor that contributes to reduced feed intake. Given that the administration of glucose and insulin prevents hypophagia (Houpt, 1994), infusions of insulin antibodies increase appetite (McGowan et al., 1992). Prolonged administration of glucose and insulin during the hyperinsulinaemiceuglycaemic method for evaluating insulin resistance decreases feed intake (McGuire et al., 1995; Griinari et al., 1997; Annen et al., 1998; Marcle et al., 1999). These effects of insulin can be of significance for cows in the dry period, but its influence on appetite in early lactation is probably not significant because its concentration is reduced. Interestingly, feed intake in cows with greater body condition scores is significantly reduced after calving. In these cows, insulin concentration is greater in the peripartal period (Holtenius et al., 2003; Roche et al., 2009; Bobowiec et al., 2011).

\section{Insulin resistance, definition and pathogenesis}

Insulin resistance is a state in which the biological effect of insulin is reduced when compensatory mechanisms induce an increase in its concentration (Cefalu, 2001). Insulin resistance is characterized by reduced insulin responsiveness to glucose i.e. reduced function of beta pancreatic cells (insulin hyporesponsiveness) and/or reduced sensitivity of glucose to insulin i.e. reduced entrance of glucose to tissues under the influence of insulin (insulin sensitivity) (Kahn, 1978). Insulin resistance can be caused by prereceptor abnormalities (reduced secretion and/or increased insulin degradation), receptor abnormalities (reduced number of receptors and/or reduced affinity of receptors for insulin) and post-receptor abnormalities (defects in cellular signalization and translocation of glucose transporters) (Hayirli, 2006). 
Insulin resistance in the peripartal period is necessary for the udder, an insulin-independent organ, to have enough nutrients and energy for lactation which starts. The phenomenon of insulin resistance is most pronounced after calving. Response of insulin to glucose is reduced and clearance of glucose is greater in post-partal period than in pre-partal period (Holtenius et al., 2003; Bossaert et al., 2008). During lactation, the udder expresses insulin independent glucose transporters, even three times greater than in the dry period. These receptors were found in fat tissue in cows during late lactation and dry period but not in cows in peak lactation. Activation of insulin sensitive receptors in skeleton muscles and fat tissue remains unchanged during lactation or in the dry period (Komatsu et al., 2005). In addition to reduced insulin response to glucose, insulin sensitivity of peripheral tissues is unchanged but greater insulin clearance rates in mid lactation have been found compared to the dry period (Sano et al., 1993). Reduction in insulin sensitivity of tissues was found in a study where hyperinsulinaemic-euglycaemic clamp was used (Mashek et al., 2001).

Malnutrition and reduced feed intake reduce insulin secretion and insulin response to glucose (Meadler et al., 2001). Cows fed reduced nutrients showed a low insulin response after glucose administration even two weeks after calving compared to cows fed ad libitum. Nutrients, especially fats, can affect the degree of insulin resistance. Therefore, short-term hyperlipidaemia caused by the intravenous administration of sterile fat increases the basal concentration of glucose and insulin with reduced clearance of glucose after a load test. However, some fatty acids (from linseed oil) can be used for improvement of insulin sensitivity and antilipolytic effect of insulin in fat tissue (Piers et al., 2007a, b, 2008). Zhang et al. (2013) noted that the intake of high-energy feed before calving reduces the expression of genes for insulin receptors in fat tissue during the postpartal period. Genetic predisposition and productivity of cows are significant factors that influence the development of insulin resistance. Highselection cows and cows that produce high milk amounts showed significantly greater insulin resistance and a slow reduction of glucose concentrations at the basal level after the glucose tolerance test (Swali and Wathes, 2006; Chagas et al., 2009).

Effects of insulin resistance are dependent on the number of tissues showing insulin resistance at a given moment. This mainly refers to fat, muscle and liver tissue. In fat tissue, insulin resistance causes a reduction in lipogenesis and an increase in lipolysis. In the peripartal period, blood NEFA concentrations are increased due to lipid mobilization. Higher NEFA concentrations are related to reduced insulin sensitivity of fat tissue in cows that are not in lactation or to reduced clearance of glucose and insulin after glucose load in dairy cows (Bossaert et al., 2009; Oikawa and Oetzel, 2006). High NEFA concentrations depress insulin-stimulated glucose uptake in skeletal muscles and suppress gluconeogenesis in the liver (Hayirly, 2006). Laboratory mouse models showed a direct influence of NEFA on beta pancreatic cells (Meadler et al., 2001). 
Speaking of muscle tissue, it has been known that insulin induces a suppression of protein catabolism while insulin deficiency can cause protein catabolism in order to use amino acids for gluconeogenesis. In insulin resistance, synthesis of glycogen in muscles is reduced due to reduced intracellular translocation of glucose. An insulin dose high enough to increase protein anabolism is much higher than the dose of insulin that protects the catabolism of existing proteins. Based on this, it is obvious that insulin has a protective role. Glucose in the liver is used by insulin-independent receptors but the presence of insulin is necessary to allow crucial metabolic processes. Insulin induces glycogen synthesis, while reducing gluconeogenesis and synthesis of ketone bodies. Mitotic effects of insulin (and growth hormone) are reflected in IGF-I production. In a state of insulin deficiency, such as starvation, all processes can be equally affected. However, under conditions of insulin resistance, these changes are not always equal. For example: insulin resistance in starvation can cause increased gluconeogenesis, but under classic insulin resistance, when compensatory insulin concentrations increase, the mitotic action of insulin on hepatocytes is present and IGF-I concentration increases. Disturbance in lipoprotein metabolism is an important indicator of insulin resistance in hepatocytes. Greater concentrations of NEFA entering the liver with reduced catabolism of VLDL in adipocytes increase the accumulation of triglycerides in hepatocytes. The entry of proinflammatory cytokines from lysed fat tissue during insulin resistance stimulates hepatocytes to produce acute phase proteins. All of the above changes were described by Wilcox (2005) and Reaven (2004) in their review papers.

Insulin resistance can be related to disturbed health of cows in the peripartal period. For example, ketotic cows show significantly reduced insulin concentrations after glucose load (Đoković et al., 2007, 2009, 2017). Another serious health problem in the peripartal period is fat infiltration of hepatocytes, a consequence of metabolic stress. Lipid accumulation in the liver is directly correlated with reduced insulin sensitivity and reduced insulin response to stimulation (Ohtsuka et al., 2001; Oikawa and Oetzel, 2006). Release of inflammatory mediators such as tumor necrosis factor alpha (TNF- $\alpha$ ) during sickness can interfere with insulin sensitivity in cattle (Kushibiki et al., 2001).

Body condition is a major factor in the development of insulin resistance. Cows with greater body condition scores and obese cows develop significant insulin resistance during the peripartal period (Holtenius and Holtenius, 2007). This can be explained by the fact that obese cows have higher amounts of NEFA from fat in the period after calving, which correlates with TNF- $\alpha$ release.

Treatment with niacin caused dual changes in insulin resistance: decreased NEFA concentrations led to a decrease in insulin resistance (due to an increase in both insulin efficiency and the insulin sensitivity index), but increased concentrations of insulin and glucose possibly caused an increase in insulin resistance in dairy cows (due to the lower insulin sensitivity index and possibly lower antilipolytic effects of insulin) (Hristovska et al., 2017). 
Heat stress is an important factor affecting insulin sensitivity in dairy cows. Results (Majkić et al., 2017) showed that: a) Cows exposed to heat-stress (high THI index) have lower milk production, higher concentrations of insulin and lower concentrations of glucose and NEFA; b) indices of insulin resistanceRQUICKI, insulin:glucose and insulin:NEFA are higher in cows under heat stress. The decrease in glucoses followed by an increased insulin level and increased insulin sensitivity indicate that glucose is transferred from the udder to other tissues, which can cause decreased milk production.

\section{Measurement of insulin resistance}

Since insulin production is affected by numerous factors, such as insulin sensitivity of tissue, many methods for the degree of insulin resistance were developed.

These methods include: direct methods (hyperinsulinaemic- euglicaemic clamp, insulin suppression test), indirect methods (minimal model analysis of frequently sampled intravenous glucose tolerance test, oral glucose tolerance test) and surrogate methods (indices calculated from basal concentrations of insulin and glucose; these indices are: 1/insulin, insulin: glucose ratio, HOMA, QUICKI, RQUICKI, and indices calculated from dynamic tests that include Matsuda index, Gutt index, Avignon index and Stimvoll index). For all insulin resistance indices, exact formulas and their characteristic interpretations have been provided (Singh and Saxena, 2010).

Insulin response and functional capacity of pancreatic beta cells are examined after the intake of standard concentrations of glucose, propionate, glucagon and other insulin stimulators. Hyperinsulinaemic-euglycaemic clamp-HIEC is the gold standard for this evaluation. In this test, insulin and glucose are infused simultaneously in order to keep euglycaemia. It is necessary to determine the glucose concentration needed to neutralize high levels of insulin and keep glucose concentrations within physiologic limits; that is, itis necessary to determine glucose and insulin concentrations and their relations during the test and compare basal conditions before measurements. These tests are not very suitable for everyday farm conditions and they are used for experimental purposes. The test used in everyday conditions is the intravenous glucose tolerance test-GTT. This test determines the basal concentration of insulin, the peak concentration of insulin and the time needed to return the concentrations to the basal levels. The universal indicator that integrates all of these parameters is area under the curve of insulin concentration (AUC). The evaluation of insulin sensitivity is conducted by the intravenous insulin tolerance test-ITT. Glucose response to exogenous insulin is determined. Nowadays, in Holstein cows, insulin resistance is evaluated by the value given by the RQUICKI formula (revised quantitative insulin sensitivity check index). This is a mathematical formula which is used for evaluating the homeostasis of energy balance which 
integrates the determination of glucose, insulin and NEFA concentrations. Characteristics of some tests, their usability, test performance problems, result interpretation problems and test development prospects are dealt with in the review paper of Muniyappa et al. (2007).

Surrogate indices of insulin resistance underlie the direct and indirect methods, such as hyperinsulinaemic-euglicaemic clamp and glucose load test. Experiments showed that indicators such as HOMA, QUICKI, RQUICKI have high values of coefficients of correlation with calculated indicators of insulin sensitivity determined by the HIEC method. Haarstrichs (2011) observed a positive correlation between insulin indices from HIEC and QUICKI and RQUICKI indices. An inverse, negative correlation was noted with the HOMA index. This author used increased insulin concentrations and the obtained results are related to measurements using the lowest insulin concentration that represents insulin sensitivity. The coefficient of determination was determined as the correlation of insulin resistance indicators with the results of the intravenous glucose tolerance test. Balogh et al. (2008) found negative correlations between RQUICKI and the parameters given after the glucose tolerance test (glucose peak, glucose dynamics over time, AUC of glucose). Also, RQUICKI showed greater correlation with hyperinsulinaemic-euglicaemic clamp compared to QUICKI and HOMA indices (Rabasa-Lhoret et al., 2003). This indicates that the use of indicators such as HOMA, QUICKI an RQUICI is justified when evaluating insulin resistance. Recent results of Alves Nores et al. (2017) have shown no significant correlation between surrogate indices of insulin resistance and parameters determined during IVGTT in early lactation. However, the use of these indices has certain advantages.

The use of insulin resistance indices in evaluating the metabolic status of cows is possible. Cincović et al. (2017) found the following: HOMA showed a positive correlation with BHB and a negative correlation with IGF-I. QUICKI showed a positive correlation with IGF-I and cholesterol, but a negative correlation with BHB and BCS. RQUICKI showed positive correlations with IGF-I, T4 and triglycerides but negative correlations with cortisol, STH, BHB, total bilirubin and BCS (body condition score).

During the intravenous glucose tolerance test in healthy and ketotic cows, RQUICKI and RQUICKI-BHB values were determined as the correlation between basal and dynamic responses of glucose, insulin, NEFA and BHB. Results showed (Đoković et al., 2017) that the RQUICKI index is significantly linearly correlated $(\mathrm{P}<0.05)$ with the basal values of insulin, glucose, NEFA and BHB. The values of the RQUICKI-BHB index showed a negative correlation with the basal values of NEFA, BHB and their clearance during the intravenous glucose tolerance test $(\mathrm{P}<0.01)$ as with the clearance of glucose $(\mathrm{P}<0.05)$, where a positive correlation was observed with the basal values of insulin and glucose response during IVGTT. The relationship of basal and dynamic responses of 
NEFA, BHB, insulin and glucose is significantly determined by RQUICKI-BHB index values.

Surrogate indices of insulin resistances were significant during the examination of the correlation between phosphorus and insulin resistance (Cincovic et al., 2017a). During IVGTT, blood phosphorus concentrations dropped, which was correlated with glucose concentrations and the ability of an organism to use glucose. The response of inorganic phosphorus (Pi AUC) was positively correlated with glucose response (glucose AUC) and correlation was affected by glucose response to insulin (insulin AUC). Pi AUC showed a positive correlation with the maximal glucose concentration and insulin during IVGTT, AUC and AUC increment for glucose, insulin and CR of glucose. All correlations were controlled by the values of RQUICKI and RQUICKI-BIB indices The reduction of Pi during the intravenous glucose tolerance test in dairy cows was correlated with all aspects of insulin resistance showing the response of insulin to glucose (insulin AUC) and the response of tissue to insulin (RQUICKI and RQUICKI-BHB).

RQUICKI index for insulin resistance is dependent on NEFA values in early lactation, but on insulin and glucose values in the dry period (Cincović et al., 2014).

IVGTT is not a suitable method for measuring insulin sensitivity of tissue in heifers during pregnancy and lactation due to differences in insulin secretion and action in different physiological conditions (De Koster et al., 2017).

\section{Limitations and specifications in ruminants during the evaluation of insulin resistance}

As regards the evaluation of insulin resistance in ruminates, it should be considered that glycaemia is dependent on the degree of gluconeogenesis in the liver. The second important limitation is that cows have a large rumen, which long after feeding is the source of nutrients which enter the blood stream and affect glucose and insulin. Therefore, hyperinsulinaemic-euglicaemic clamp is highly usable as it eliminates gluconeogenesis in hepatocytes from analysis and the test is performed after starvation. The third limitation is dyslipidaemia in insulin resistance. The main metabolic adaptation in diabetes mellitus type II is an increased lipid concentration, which ensues after increased lipolysis in adipose tissue (Mihajlović and Jovanović, 2008). During early lactation, greater lipid mobilization occurs in cows in response to insulin resistance; therefore, hepatocytes become loaded and cannot synthesize adequate amounts of apolipoprotein VLDL. This causes reduced cholesterol levels and reduced triglyceride levels because they are accumulated in hepatocytes. 


\section{Acknowledgement}

This research was supported by the Ministry of Education, Science and Technological Development of Serbia through Projects Nos. TR31062 and TR31095.

\section{References}

Alves-Nores V., Castillo C., Hernandez J., Abuelo A. (2017): Comparison of surrogate indices for insulin sensitivity with parameters of the intravenous glucose tolerance test in early lactation dairy cattle. Domestic animal endocrinology, 61: 48-53.

Anil M.H., Forbes J.M. (1980): Feeding in sheep during intraportal infusions of shortchain fatty acids and the effect of liver denervation. Journal of Physiology, 298: 407-414.

Annen E.L., McGuire M.A., Hanson T. W., Bauman D.E. (1998): Milk protein production in cows subjected to abomasal infusion of branched-chain amino acids (BCAA) and hyperinsulinemic-euglycemic clamp. Journal of Dairy Science, 81:354 (Abstr.).

Balogh O., Szepes O., Kovacs K., Klucsar M., Reiczigel J., Alcazar J.A., Keresztes M., Febel H., Bartyik J., Fekete S.G., Fesus L., Huszenicza G. (2008): Interrelationship of growth hormone AluI polymorphysm, insulin resistance, milk production and reproductive performance in Holstein-Friesian cows. Veterinarni Medicina, 53: 604616.

Bobowiec R., Kierska M., Kosior-Korzecka U. (2011): Insulin sensitivity in highproducing lactating cows. Medycyna Weterynaryjna, 67: 181-185.

Bossaert P. , Leroy J.L.M.R., De Campeneere S., De Vliegher S., Opsomer G. (2009): Differences in the glucose induced insulin response and the peripheral insulin responsiveness between neonatal calves of the Belgian Blue, Holstein-Friesian, and East Flemish breeds. Journal of Dairy Science, 92:4404-4411.

Cefalu W.T. (2001): Insulin resistance: cellular and clinical concepts. Experimental Biology and Medicine (Maywood), 226: 13-26.

Chagas L.M., Lucy M.C., Back P.J., Blache D., Lee J.M., Gore P.J.S., Sheahan A.J., Roche J.R. (2009): Insulin resistance in divergent strains of Holstein-Friesian dairy cows offered fresh pasture and increasing amounts of concentrate in early lactation. Journal of Dairy Science, 92: 216-222.

Cincović M. R., Belić B., Đoković R., Toholj B., Hristovska T., Delić B., Došenović M. (2014): Insulin resistance in cow during dry period and early lactation. Contemporary agriculture, 63: 98-105.

Cincović M.R., Djoković R., Belić B., ... \& Starič, J. (2017a): Inorganic phosphorus decrease after intravenous glucose tolerance test is associated with insulin resistance in dairy cows. Veterinarski arhiv, 87: 409-418.

Cincović M., Kirovski D., Vujanac I., Belić B., Djoković R. (2017): Relationship between the indexes of insulin resistance and metabolic status in dairy cows during early lactation. Acta Veterinaria, 67: 57-70.

Deetz L.E., Wangsness P.J. (1980): Effect of intrajugular administration of insulin on feed intake, plasma glucose and plasma insulin of sheep. The Journal of Nutrition, 110: 1976-1982. 
De Koster J., Van Eetvelde M., Hermans K., Van Den Broeck W., Hostens M., Opsomer G. (2017): Limitations of glucose tolerance tests in the assessment of peripheral tissue insulin sensitivity during pregnancy and lactation in dairy heifers. Journal of dairy science, 100: 2381-2387.

Djoković R., Dosković V., Cincović M., Belić B., Fratrić N., Jašović B., Lalović M. (2017): Estimation of Insulin Resistance in Healthy and Ketotic Cows during an Intravenous Glucose Tolerance Test. Pakistan Veterinary Journal, 37: 4.

Đoković R., Šamanc H., Ilić Z., Kurćubić V. (2009): Changes in blood values of glucose, insulin and inorganic phosphorus in healthy and ketotic cows after intravenous infusion of glucose solution. Acta Veterinaria Brno, 78: 385-389.

Đoković R., Šamanc H., Nikolić Z., Bošković-Bogosavljević S. (2007): Changes in blood values of glucose, isnulin and inorganic phophorus in healthy and ketotic cows after intravenous infusion of propionate solution. Acta Veterinaria Brno, 76: 533-539.

Đoković R., Dosković V., Cincović M., Belić B., Fratrić N., Jašović B., Lalović M. (2017): Estimation of Insulin Resistance in Healthy and Ketotic Cows during an Intravenous Glucose Tolerance Test. Pakistan Veterinary Journal, 37(4): 387-392.

Foster L.A., Ames N.K., Emery R.S. (1991): Food intake and serum insulin responses to intraventricular infusions of insulin and IGF-I. Physiology \& Behavior, 50: 745-749.

Griinari J.M., McGuire M.A., Dwyer D.A., Bauman D.E., Palmquist D.L. (1997): Role of insulin in the regulation of milk fat synthesis in dairy cows. Journal of Dairy Science, 80:1076-1084.

Haarstrich D. (2011): Evaluation of surrogate indices of insulin sensitivity by means of hyperinsulinemiceuglycemic glucose clamps in dairy cows; u: Insulinsensitivität und Insulinresponse nach einer Langzeit-Supplementation von konjugierten Linolsäuren bei laktierenden Milchkühen. Inaugural dissertation. Tierärztliche Hochschule Hannover.

Hayirli A. (2006): The role of exogenous insulin in the complex of hepatic lipidosis and ketosis associated with insulin resistance phenomenon in postpartum dairy cattle. Veterinary Research Communications, 30: 749-774.

Holtenius K., Agena S., Delavaud C., Chilliard Y. (2003): Effects of feeding intensity during the dry Period. 2. Metabolic and hormonal responses. Journal of Dairy Science,86: 883-891.

Houpt T.R. (1974): Stimulation of food intake in ruminants by 2-deoxy-D-glucose and insulin. American Journal of Physiology, 227:161-167.

Hristovska T., Cincović M. R., Belić B., Stojanović D., Jezdimirović M., Đoković R., Toholj B. (2017): Effects of niacin supplementation on the insulin resistance in Holstein cows during early lactation. Acta Veterinaria Brno, 86 (3): 231-238.

Kahn S.E., Hull R.L., Utzschneider K.M. (2006): Mechanisms linking obesity to insulin resistance and type 2 diabetes. Nature, 444: 840-846.

Komatsu T., Itoh F., Mikawa1 S., Hodate K. (2005): Changes in gene expression of glucose transporters in lactating and nonlactating cows. Journal of Animal Science, 83: 557-564.

Kulkarni R.N. (2004): The islet betal-cell. The International Journal of Biochemistry \& Cell Biology, 36: 365-71.

Kushibiki S., Hodate K., Shingu H., Ueda Y., Mori Y., Itoh T., Yokomizo Y. (2001): Effect of long-term administration of recombinant bovine TNF alpha on glucose 
metabolism and hormone secretion in Holstein steers. American Journal of Veterinary Research, 62: 794-798.

Maedler K, Spinas GA, Dyntar D, Moritz W, Kaiser N, Donath MY (2001): Distinct effects of saturated and monounsaturated fatty acids on ß-cell turnover and function. Diabetes, 50: 69-76

Majkić M., Cincović M. R., Belić B., Plavša N., Lakić I., Radinović, M. (2017): Relationship between milk production and metabolic adaptation in dairy cows during heat stress. Acta agriculturae Serbica, 22 (44): 123-131.

Marcle T.R., Dwyer D.A., Ingvartsen K.L., Chouinard P.Y., Bauman D.E. (1999): Effect of insulin and amino acids on milk protein concentration and yield from dairy cows. Journal of Dairy Science, 82: 1512-1524.

Mashek D.G., Ingvartsen K.L., Andersen J.B., Vestergaard M., Larsen T. (2001): Effects of a fourday hyperinsulinemic-euglycemic clamp in early and mid-lactation dairy cows on plasma concentrations of metabolites, hormones, and binding proteins. Domestic Animal Endocrinology, 21: 169-185.

McGowan M.K., Andrews K.M., Grossman S.P. (1992): Chronic intrahypothalamic infusions of insulin or insulin antibodies alter body weight and food intake in the rat. Physiology \& Behaviour, 51: 753-766.

McGuire M.A., Griinari J.M., Dwyer D.A., Bauman D.E. (1995): Role of insulin in the regulation of mammary synthesis of fat and protein. Journal of Dairy Science, 78: 816-824.

Mihajlović M.B., Jovanović I.B. (2008): Biohemija. Fakultet veterinarske medicine, Beograd.

Muniyappa R., Lee S., Chen H., Quon M.J. (2008): Current approaches for assessing insulin sensitivity and resistance in vivo: advantages, limitations, and appropriate usage. American Journal of Physiology-Endocrinology and Metabolism, 294:E15E26.

Ohtsuka H., Koiwa M., Hatsugaya A., Kudo K., Hoshi F., Itoh N., Yokota H., Okada H., Kawamura S. (2001): Relationship between serum tumor necrosis factor-alpha activity and insulin resistance in dairy cows affected with naturally occurring fatty liver. The Journal of Veterinary Medical Science, 63: 1021-1025.

Oikawa S., Oetzel G.R. (2006): Decreased insulin response in dairy cows following a four-day fast to induce hepatic lipidosis. Journal of Dairy Science, 89: 2999-3005.

Pavlović B., Pavlović V. (2007): Leksikon nobelovaca-naučna elita XX veka. Prosveta Beograd.

Pierzynowski S.G., Zabielski R. (1999): Biology of the Pancreas in Growing Animals. Elsevier health science.

Pires J.A.A., Pescara J.B., Brickner A.E., del Rio S.N., Cunha A.P., Grummer R.R. (2008): Effects of abomasal infusion of linseed oil on responses to glucose and insulin in Holstein cows. Journal of Dairy Science, 91: 1378-1390.

Pires J.A.A., Pescare J.B., Grummer R.R. (2007a): Reduction of plasma NEFA concentration by nicotinic acid enhances the response to insulin in feed-restricted Holstein cows. Journal of Dairy Science, 90: 4635-4642.

Pires J.A.A., Souza A.H., Grummer R.R. (2007b): Induction of hyperlipidemia by intravenous infusion of tallow emulsion causes insulin resistance in Holstein cows. Journal of Dairy Science, 90: 2735-2744. 
Rabasa-Lhoret R., Bastard J.P., Jan V., Ducluzeau P.H., Andreelli F., Guebere F., Bruzeaz J., Louche-Pellissier C., Maitrepiere C., Peyrat J., Change J. , Vidal H., Laville M. (2003): Modified Quantitative Insulin Sensitivity Check Index Is Better Correlated to Hyperinsulinemic Glucose Clamp than Other Fasting-Based Index of Insulin Sensitivity in Different Insulin-Resistant States. The Journal of Clinical Endocrinology \& Metabolism, 88: 4917-4923.

Reaven G. (2004): The metabolic syndrome or the insulin resistance syndrome? Different names, different concepts, and different goals. Endocrinology and Metabolism Clinics of North America, 33: 283-303.

Roche J.R., Friggens N.C., Kay J.K., Fisher M.W., Stafford K.J., Berry D.P. (2009): Invited review: Body condition score and its association with dairy cow productivity, health, and welfare. Journal of Dairy Science, 92: 5769-5801.

Sano H., Narahara S., Kondo T., Takahashi A., Terashima Y. (1993): Insulin responsiveness to glucose and tissue responsiveness to insulin during lactation in dairy cows. Domestic Animal Endocrinology, 10: 191-197.

Singh B., Saxena A. (2010): Surrogate markers of insulin resistance: A review. World Journal of Diabetes, 1: 36-47.

Swali A., Wathes D.C. (2006): Influence of the dam and sire on size birth and subsequent growth, milk production and fertility in dairy heifers. Theriogenology, 66: 1173-1184.

Wilcox G. (2005): Insulin and Insulin Resistance. Clinical Biochemist Reviews, 26: 1939.

Zhang Z., Wang J., Gao R., Zhang W., Li X., Liu G., Li X., Wang Z., Zhu X. (2013): High-energy diet at antepartum decreases insulin receptor gene expression in adipose tissue of postpartum dairy cows. Bulletin of the Veterinary Institute Pulawy, 57: 203-207. 


\title{
INSULINSKA REZISTENCIJA KOD KRAVA U PERIPARTALNOM PERIODU (PREGLED)
}

\author{
Marko R. Cincović ${ }^{1}$, Radojica Đoković ${ }^{2}$, Branislava Belić ${ }^{1}$, Ivana \\ Lakić $^{1}$, Nenad Stojanac ${ }^{1}$, Ognjen Stevančević ${ }^{1}$, Nenad Staničkov ${ }^{1}$ \\ ${ }^{1}$ Univerzitet u Novom Sadu, Poljoprivredni fakultet, Departman za veterinarsku \\ medicinu, \\ Trg Dositeja Obradovića 8, 21000 Novi Sad, Srbija \\ ${ }^{2}$ Univerzitet u Kragujevcu, Agronomski fakultet Čačak, Cara Dušana 34, Čačak, \\ Srbija

\section{Rezime}

Insulinska rezistencija je stanje u kome je smanjen biološki efekat insulina, u uslovima kada opada njegova koncentracija ili kada kompenzatorno može doći do povećanja njegove koncentracije. Insulinska rezistencija se karakteriše smanjenim odgovorom insulina na glukozu tj. smanjenom funkcijom beta ćelija pankreasa (eng. insulin hyporesponsiveness) i/ili smanjenom osetljivošću glukoze na insulin tj. smanjenim ulaskom glukoze u tkivo pod dejstvom insulina (eng. insulin sensitivity). Metode za merenje insulinske rezistencije mogu se podeliti na: direktne (hiperinsulinemijski euglikemijski klamp, zlatni stadard), indirektne (intravenski glukoza tolerans test) i surogat metode (indeksi dobijeni iz bazalne koncentracije insulina, glukoze, NEFA i BHB - HOMA, QUICKI, RQUICKI i RQUICKI-BHB). Surogat indeksi pokazuju povezanost sa rezultatima iz direktnog i indirektnog testa, ali su rezultati nekonzistentni. Nekonzistentnost nastaje jer prilikom procene insulinske rezistencije kod preživara treba imati u vidu da je glikemija zavisna od stepena glukoneogeneze koja se odvija u jetri. Zbog toga je hiperinsulinemijski-euglikemijski klamp metod posebno kvalitetan jer u potpunosti isključuje glukoneogenezu u hepatocitima iz analize. Naši rezultati su pokazali da postoji korelacija HOMA, QUICKI i RQUICKI indeksa sa parametrima metaboličkog profila. Povezanost bazalnog i dinamičkog odgovora NEFA, BHB, insulina, glukoze i neorganskog fosfora značajno je determinisana vrednostima RQUICKI-BHB indeksa kod krava u ketozi. RQUICKI indeks insulinske rezistencije značajno je determinisan vrednostima NEFA u ranoj laktaciji i vrednostima insulina i glukoze u periodu zasušenja. Dalja istraživanja treba usmeriti ka praktičnoj evaluaciji upotrebe indeksa insulinske rezistencije.

Ključne reči: indeksi insulinske rezistencije, krave, metabolički status, rana laktacija. 